\title{
Redaksjonelt:
}

\section{Klarspråk och klarspråksarbete - ett tema i tiden}

\section{Klarspråk - en nordisk specialitet}

I de nordiska länderna finns i dag ett stort intresse för det språkpolitiska arbetet med att modernisera och demokratisera det offentliga språket. Benämningen klarspråk, som här kommer att användas om detta språkarbete, är från början svensk och började användas av en grupp språkvårdare i det svenska regeringskansliet i början av 1990-talet. Utan att klarspråk kan sägas vara särskilt stringent definierat, har det sedan dess kommit att beteckna en strävan efter ett klart och begripligt myndighetsspråk, i akt och mening att underlätta kommunikationen framför allt mellan medborgare och myndigheter. Tidiga texter som väckte språkvårdens intresse var lagar och andra författningar, utifrån en ganska ambitiös tanke om att alla medborgare - som ju formellt har rätt att läsa lagförslag - också skulle kunna göra det och därmed få bättre insyn i de demokratiska processerna, och större möjligheter att påverka dem. ${ }^{1}$

Tanken på en språkligt okomplicerad kommunikation mellan medborgare och myndigheter är förstås inte något som uppstått enbart i den svenska språkvården. De nordiska länderna har alla, vart och ett på sitt sätt, drivit de här frågorna och under de senare åren har samarbetet mellan länderna intensifierats. År 1998 hölls den första nordiska klarspråkskonferensen i Stockholm och det är ett forum som blivit återkommande - under 2015 hålls den nionde nordiska klarspråkskonferensen i Oslo. Dessa konferenser har inte bara varit viktiga för diskussionen om klarspråk utan också bidragit till att skapa och sprida publikationer om klarspråk. Ett gemensamt nordiskt projekt är också antagandet av Deklarationen om nordisk språkpolitik, där det fastslås att "Norden skall eftersträva att vara ledande inom det område som kallas klarspråksarbete, d.v.s. att göra myndighetsspråket tydligare" (Deklaration om nordisk språkpolitik 2007, s. 84 f.). Några axplock från den nordiska klarspråkshistorien fram till idag kan få bilda utgångspunkt för den här introduktionen till ett nordiskt klarspråksnummer.

I Norge har man ganska sent tagit upp benämningen klarspråk, men arbetet med myndighetsspråk har bedrivits länge - bland annat med utgångspunkt i professor Finn-Erik Vinjes "ti språkvettregler", formulerade i analogi med de välkända norska reglerna för fjällvett. Professor Ruth Vatvet Fjelds Norsk til kontorbruk (fjärde upplagan 2002) har varit en fortlöpande facklitterär succé sedan 1988. I Norge bedrevs under perioden 2008-2013 det stora projektet "Klart språk i staten", som innebar en omfattande utbildnings- och seminarieverksamhet, inrättandet av ett klarspråkspris liksom insatser för att stimulera till klarspråksforskning. Satsningen på klart språk i staten har bland annat avsatt projektet "Klart lovspråk", samt uppmärk-

\footnotetext{
${ }^{1}$ Om hur det svenska arbetet med myndighetsspråkvård uppstår kan man läsa i Nämnd, inte glömd (Lindgren 2007a), särskilt artiklarna av Grünbaum (2007) och Lindgren (2007b).
} 
sammade masteruppsatser om klarspråk i Arbeids- og velferdsforvaltningen, NAV, (Furu 2011, Seljeseth 2013) och webbplatsen Klarspråk (http://www.sprakradet.no/klarsprak).

I Finland antogs i januari 2014 ett handlingsprogram för klart myndighetsspråk (Klart myndighetsspråk - ett handlingsprogram 2014). Det är ett gott exempel på hur samhällets ledning och språkvården förenas i ansträngningar om det goda språket. I det inledande sammandraget till handlingsprogrammet finns nedanstående formuleringar som kan stå som handlingsförklaring till klarspråksarbete i alla de nordiska länderna. Det handlar om att spara tid och pengar, att stärka rättssäkerheten och inte minst om att inse språkets roll i myndigheternas arbetsprocesser. I formuleringarna tar man också ställning till fördelningen mellan myndigheternas egna medarbetare och det som här kallas språkexperter.

Språket är inte ett fristående element som kan lämnas åt några enstaka personer att ta hand om, utan språket berör alla inom den offentliga förvaltningen, allt från de högsta beslutande organen till ledningen för de olika myndigheterna och varje enskild medarbetare. För att klarspråksmålet ska nås måste varje myndighet ha som rutin att utvärdera sitt språk och att anlita språkexperter när behovet är påkallat. Det går att spara tid och möda genom att använda ett klart och begripligt språk. Dessutom effektiverar ett klart språk myndigheternas verksamhet och stärker medborgarnas rättssäkerhet. (Klart myndighetsspråk - ett handlingsprogram 2014)

I Danmark har forskaren Anne Kjærgaard genomfört en stor undersökning av vilka effekter genomförda klarspråksinsatser får vid två myndigheter. Kjærgaards avhandling (2010, sammanfattad i Kjærgaard 2012) är ett sällsynt exempel på att arbetet med klarspråk faktiskt beforskas. Av undersökningen framgår att en del av klarspråksinsatserna faktiskt får ganska litet genomslag, och att detta inte beror primärt på språkliga frågor, utan snarare på organisatoriska. Det kan till exempel handla om att de som initierar språkvårdsinsatserna och de som ska genomföra arbetet inte är överens om den inledande problembeskrivning som är skäl till att insatserna prioriteras. Genomförandet av klarspråksinsatser är alltså en ganska komplex process, som inte bara kräver språkvetenskaplig kompetens, utan också kompetens inom områden som organisationsteori och projektledning.

Under de år som har gått sedan klarspråk blev ett samlande begrepp för myndighetsspråkvård i Sverige - och så småningom i Norden - har det kommit många råd om klarspråk och många handböcker. Frågan har i viss utsträckning blivit en angelägenhet för dem som arbetar med den i praktiken: anställda på olika myndigheter, språkvårdare som arbetar med textbearbetning och skribentutbildning samt textgranskare i lagstiftningsarbetet. Däremot har det inte skett så mycket forskning inom klarspråkets område. Kjærgaards studie utgör ett positivt undantag, men i övrigt är studierna få, ${ }^{2}$ trots att forskningsperspektiv har efterlysts i flera sammanhang (Josephson 2009, Nyström Höög 2009). Det är en av anledningarna till att vi nu sätter samman ett temanummer om klarspråk i tidskriften Sakprosa.

\footnotetext{
2 Se för översikter av tidigare forskning t.ex. Kjærgaard 2010, Nord 2011, Nyström Höög, Söderlundh \& Sörlin 2012 och Bendegard 2014.
} 
För att området ska kunna utvecklas krävs det, menar vi, utvecklad forskningsunderbyggnad och ökad teoretisk förståelse av vad språkplaneringsprojektet klarspråk innebär. Forskningen kan bidra med granskning av praxis och med argument och problematisering. Den kan bidra med en blick för övergripande sammanhang som kanske inte är så tydliga för den som är mitt $i$ arbetet och den kan bidra med nya teoretiska och empiriska kunskaper. Detta temanummer är avsett att understödja dialogen mellan forskning och praktiskt klarspråksarbete - och gärna leda till att det praktiska klarspråksarbetet utvecklas genom att ge underlag för reflektion.

\section{Varför klarspråk just nu?}

Myndigheternas kommunikationspraktiker är stadda i snabb förvandling, och det innebär naturligtvis att språkvården återkommande ställs inför nya utmaningar. Sedan klarspråksverksamheten tog sin början är det kanske två samhällsförändringar som fått särskilt stor effekt på de nordiska myndigheterna. Den första av dessa är digitaliseringen. Omställningen från pappers- eller telefonkommunikation till kommunikation via webbplatser och e-post, har dels påverkat myndigheternas genrerepertoar, dels påverkat själva textutformningen och inte minst myndigheternas tilltalsmönster. Det framgår till exempel i Linnea Hanells (2012) undersökning att flera myndigheter satsar stora resurser på sin webbkommunikation. Två konsekvenser av detta är för det första att allt större ansvar läggs på medborgaren att hitta fram till informationen, istället för att få den skickad till sig, och för det andra att kommunikationen i allt större utsträckning blir multimodal. Framför allt innebär kommunikation i digitala medier att nya typer av multimodalitet uppstår. När textstruktur och länksystem och samspel mellan texter blir minst lika viktiga som meningslängd, interpunktion och val av termer aktualiseras delvis annorlunda nya krav på användarvänlighet. T.ex. kan ju ett digitalt formulär i vissa avseenden vara långt enklare att fylla $\mathrm{i}$ än ett tryckt formulär, men samtidigt vara långt mindre "klart" i den meningen att vi inte förstår de regler som ligger bakom nätformulärets logik.

Den andra samhällsförändringen är utvecklingen från en- eller fåspråkiga samhällen till mångspråkiga och mångkulturella samhällen. Särskilt i Sverige har antalet använda språk ökat mycket starkt och idag räknar man med uppemot 200 olika modersmål vid sidan av huvudspråket svenska och de inhemska minoritetsspråken (Domeij \& Spetz 2014). På Försäkringskassans webbplats (www.fk.se) har man som besökare möjlighet att välja mellan 22 språk utöver svenska och engelska ${ }^{3}$. Utöver kravet att myndigheternas texter ska vara skrivna på klart, enkelt och begripligt språk kommer alltså en fråga om språkval. Andra bearbetningsprinciper för mottagaranpassning finns också. I Sverige finns bland annat Centrum för lättläst, vars principer för att utarbeta texter inom det format som betecknas just "lättläst" också har slagit igenom hos flera myndigheter (Rehnberg 2012, Domeij \& Spetz 2014). Det har också blivit vanligt med uppläsningsfunktioner eller till och med att information kompletteras med filmer (Domeij \& Spetz 2014). Även om dessa format ännu är under utveckling är det alltså

\footnotetext{
${ }^{3}$ Uppgiften hämtad den 11 januari 2015.
} 
inte längre helt självklart att den optimala kommunikationsformen för myndigheterna är ett nordiskt språk i klarspråksbearbetad version (jfr också Nord 2014).

En annan aspekt av flerspråkighet handlar om förändrade internationella förhållen som i synnerhet berör EU-gemenskapen: ett stort antal av de lag- och författningstexter som reglerar vårt vardagsliv är ursprungligen skrivet på ett icke-nordiskt språk. Många författningstexter har inte ens hunnit bli auktoritativt översatta förrän de börjar gälla.

Just författningstexterna är fortsatt en av huvudnycklarna i nästan allt offentligt klarspråksarbete. Detta är ingen ny insikt, men det är något som ofta förbises. Huvuddelen av myndigheternas kommunikation grundar sig på lagar och föreskrifter. Det kan därför vara lovvärt att sträva efter att "översätta" juridiska begrepp därifrån till lekmannatermer på det sätt den amerikanske presidenten Richard Nixon krävde 1973 när han deklarerade att all text i den offentliga nyhetstidningen Federal Register skulle skrivas "in layman's terms". Samtidigt är detta ingen "quick fix", eftersom termbyten och förenklande omskrivningar ofta inte ger särskilt stor effekt. Britt-Louise Gunnarsson visade 1982 i sin välkända avhandling om lagtexters begriplighet att sådana ytspråkliga omskrivningar inte gör någon substantiell skillnad för textens begriplighet. I stället krävs mer omfattande omarbetningar som bl.a. påverkar textens perspektiv. Trots de klara resultat som presenteras av Gunnarsson (1982) har inte många insatser gjort när det gäller samarbete mellan jurister och de som ska tillgängliggöra texterna. Antalet kommunikationsmedarbetare har ökat i all nordisk förvaltning, men det är fortfarande efter många års klarspråksarbete nödvändigt att poängtera hur viktigt det är med både samarbete och ömsesidig respekt mellan professionella på språk- och kommunikationsområdet och jurister - på alla nivåer.

\section{Professionaliseringens dilemma}

I Sverige inrättades redan 1978 en tvåårig språkkonsultutbildning som från början inriktades specifikt på arbetet med myndighetsspråkvård. Sett i relation till utvecklingen av klarspråksarbetet i regeringskansliet så var utbildningen "tidigt ute" och det innebär att Sverige nu har en ganska stor grupp språkvårdare som fătt utbildning för en relativt specifik roll som myndighetsspråkvårdare. Under många år fanns utbildningen bara i Stockholm, och det finns nog en viss centrering av språkkonsulter till regionerna närmast Stockholm, men under de senaste åren har nya språkkonsultutbildningar startat och idag är det möjligt att läsa den numera treåriga utbildningen också i Umeå, Göteborg och Lund.

För den svenska myndighetsspråkvården innebär den här yrkesgruppen att det blir lättare att dela upp hanteringen av språk och övrigt arbete inom myndigheterna. Tack vare språkkonsulterna gör myndigheterna vad som i det finska handlingsprogrammet kallas för att "anlita språkexperter". I huvudsak arbetar språkkonsulterna antingen som anställda inom en myndighet, eller för egna språkföretag, vilka anlitas på konsultbasis (jfr Nord 2011, 2013). Systemet med språkkonsulter har uppenbara fördelar. Exempelvis är det en fördel att ha specialistkompetens inom myndigheten, just när det gäller det speciella register av språk som myndigheten - och kanske specifikt den egna myndigheten - använder. Det finns dock också en risk att handläggare utan specifik språkkompetens känner sig utestängda från delar av 
arbetsprocessen (jfr Söderlundh 2012). Det är därför viktigt att diskutera språkkonsultens roll. Om språkvårdsarbetet ska integreras i myndighetens arbete är det viktigt att betona språkkonsultens roll som pedagog och samordnare av språkvårdsarbete, snarare än rollen som granskare av enskilda texter (jfr Nord 2013, Rösare 2013). På sikt är det värdefullt om kompetensen om myndighetsspråk sprids på flera händer så att inte myndighetsspråkvården i sig bidrar till en syn på språk och sakfrågor som skilda åt.

\section{"Plain language"}

Arbetet med begripligt myndighetsspråk pågår i många länder i världen, men tar sig naturligtvis olika uttryck. I exempelvis England startade arbetet med Plain Language snarast som ett slags konsumentuppror mot obegripliga texter. Flera internationella organisationer är idag verksamma med att samla och sprida kunskap om klarspråksarbete. Ett par av de större är PLAIN (Plain Language Association International, http://www.plainlanguagenetwork.org) som enligt sin webbsidespresentation är en organisation för "plain language supporters and practitioners". Också Clarity (http://www.clarity-international.net), som ordnar konferenser och ger ut en tidskrift, är en betydande organisation i klarspråksvärlden. Den presenterar sig som en organisation för "lawyers and others who advocate using plain language" och har alltså en starkare tonvikt på juristkompetens. Varken PLAIN eller Clarity domineras av vetenskapliga perspektiv på språkvård, utan just av praktikernas verksamhetsnära perspektiv. I organisationerna ingår både medlemmar med hög juridisk kompetens och företag med utpräglat vinstintresse, som marknadsför råd och hjälp för klarspråksarbete. Sedan ett par år tillbaka finns också organisationen IC Clear (International consortium for clear communication, http://icclear.net), som arbetar med utbildning inom klarspråksområdet.

De nordiska länderna betraktas i många fall som framgångsrika i klarspråksarbetet, och det händer att nordiska representanter bjuds in till länder som vill närma sig, eller initiera, arbete med klarspråk/plain language. Det är naturligtvis gynnsamt för de nordiska klarspråkspraktikerna att arbetet på detta sätt uppmärksammas, men för nordiska språkforskare med inriktning mot klarspråk är det inte oproblematiskt att de internationella nätverken i klarspråkssammanhang är praktikersammanslutningar. Det finns helt enkelt ingen självklar internationell arena för vetenskaplig diskussion om klarspråksfrågor, och det kan vara en bidragande förklaring till att forskning om klarspråk inte riktigt skjutit fart - varken i Norden eller internationellt.

\section{Utmaningar för dagens klarspråksarbete}

Sedan den nordiska myndighetsspråkvården tog sin början, i slutet av 1960-talet, har det nordiska textsamhället och de nordiska samhällena genomgått stora förändringar. Några sådana har vi pekat på här - en omfattande digitalisering, en snabb förändring till mera mångspråkiga samhällen, en mera texttät och mindre formell myndighetskultur. Inom myndighetsspråkets värld har också en ny yrkeskategori textexperter vuxit fram, i språkkonsulterna, och inom forskningsvärlden har kraven ökat på att forskning ska vara internationellt gångbar. Alla de här förändringarna ställer myndighetsspråkvården inför nya utmaningar. Redan den form- 
ulering som finns i den svenska språklagen - och som har motsvarigheter i de andra nordiska länderna - om att myndighetsspråket ska vara "vårdat, enkelt och begripligt" innebär en utmaning. För hur operationaliserar man egentligen "vårdat, enkelt och begripligt" på ett sätt som är pedagogiskt och rättvisande, utan att man bortförhandlar de skillnader som finns mellan olika kommunikativa kontexter?

Vi menar att klarspråksarbetet idag står inför tre väsentliga utmaningar:

- Legitimeringen: Hur kan vi legitimera strävan efter ett begripligt myndighetsspråk i en värld som präglas av ökad språklig mångfald, och där klarspråkets mål bara blir en möjlig norm jämfört med andra krav som uppläsning, lättläst eller tolkning?

- Räckvidden: Vad ska egentligen vara fokus för arbetet och hur förhåller det sig till andra projekt för bättre kommunikation?

- Effekterna: Hur ska arbetet se ut för att uppnå de mål som ställs upp i olika måldokument?

De artiklar som ingår i detta temanummer tar sig på olika sätt an dessa utmaningar, eller aspekter av dem. De första två baseras på större undersökningar av klarspråksarbetets effekt respektive organisation: Anne Kjærgaard redovisar i sin artikel några resultat från en undersökning där ett brev från den danska skattemyndigheten (SKAT) omarbetats och testats på en grupp informanter. Saga Bendegard rapporterar från sitt avhandlingsarbete om hur klarspråk uppfattas och implementeras vid EU:s översättaravdelningar i Bryssel och Luxemburg. I Åsa Wengelins artikel diskuteras effekt och legitimitet utifrån i vilken utsträckning ett antal vedertagna svenska klarspråksråd verkligen bygger på solid forskningsevidens. Hon anlägger i huvudsak ett psykolingvistiskt perspektiv för att härleda evidensen bakom ett antal vanliga klarspråksråd, och artikeln mynnar ut i en diskussion om vilken forskning som kan lägga grund för framtida klarspråksråd om textutformning. Lena Lind Palicki och Andreas Nord diskuterar i sin artikel den transformering av klarspråkstanken som kan sägas ske från den demokratiska idédebatt som finns i grunden till de praktiska råd och principer som meddelas i klarspråksutbildningar. Artikeln problematiserar frågan om klarspråkets räckvidd och diskuterar kritiskt frågan om legitimering av den här typen av språkvård. Catharina Nyström Höög tar upp en relativt ny genre i myndigheternas textrepertoar till behandling, nämligen värdegrunder, och diskuterar med utgångspunkt i den också klarspråksarbetets räckvidd. I en avslutande essä betraktar Hans Petter Graver lagspråket, och lagspråkets makt, ur ett Kafkaperspektiv.

Det nordiska myndighetsspråket har kommit långt från den ogenomtränglighet som präglade Kafkas skildringar av mötet med staten. Men vi siktar ännu längre. Ända fram till klart språk i staten, såväl som hos regionala och kommunala myndigheter. Till hjälp i den processen eftersträvar vi en språkvård som är systematisk, målinriktad och utvärderad. Den ska vara forskningsanknuten på så sätt att både de råd som ges och de genomföranden som rekommenderas ska vara evidensbaserade. Den bör vara genomlyst av forskningen och så teoretiserad att metareflektion är möjlig. Detta temanummer av Sakprosa lämnar många av de 
ovan nämnda utmaningarna utan kommentar - till exempel saknas här i stort sett diskussioner om digitala och multimodala texter, liksom om det mångspråkiga samhället. Vi hoppas därför att temanumret både kan inspirera till ny forskning med nya artiklar på temat klarspråk och bidra till en utveckling av det nordiska klarspråksarbetet.

Andreas Nord

Göteborgs universitet

\author{
Catharina Nyström Höög \\ Högskolan Dalarna
}

\author{
Johan L. Tønnesson \\ Universitetet i Oslo
}

\section{Litteratur}

Bendegard, S. (2014). Begriplig EU-svenska? Klarspråksarbetets förutsättningar inom den interinstitutionella översättningsprocessen (Doktorsavhandling, Uppsala universitet.) Uppsala: Uppsala universitet.

Deklaration om nordisk språkpolitik (2007). (ANP 2007:746.) Köpenhamn: Nordiska ministerrådet.

Domeij, R. \& Spetz, R. (2014). Begripliga myndigheter på nätet. Hur skapar man tillgänglighet för alla i ett flerspråkigt samhälle? I J. Lindström, S. Henricson, A. Huhtala, P. Kukkonen, H. Lehti-Eklund \& C. Lindholm (Red.), Svenskans beskrivning 33. Förhandlingar vid Trettiotredje sammankomsten för svenskans beskrivning. Helsingfors den 15-17 maj 2013 (s. 52-62). Helsingfors: Helsingfors universitet.

Gunnarsson, B. L. (1982). Lagtexters begriplighet. En språkfunktionell studie av medbestämmandelagen. Lund: Liber Förlag.

Fjeld, R.V. (2002). Norsk til kontorbruk. God norsk i administrasjon og forvaltning. Oslo: Universitetsforlaget.

Furu, I.A.V. (2011). En vegg av tekst. En kvalitativ intervjuundersøkelse av skjemaet Krav om ytelse ved fødsel og adopsjon (NAV 14-05.05) (Masteroppgave, Universitetet i Oslo). Oslo: Universitetet i Oslo.

Grünbaum, C. (2007). Mitt liv med Svenska språknämnden. I B. Lindgren (Red.), Nämnd, inte glömd. Historik över Nämnden för språkvård och Svenska språknämnden 1944-2007 (s. 153-166). (Skrifter utgivna av Svenska språknämnden 95.) Stockholm: Norstedts.

Hanell, L. (2012). Texten på webben - mellan myndighet och medborgare. I C. Nyström Höög, H. Söderlundh \& M. Sörlin (Red.), Myndigheterna har ordet. Kommunikation i skrift (s. 105-122). (Språkrådets skrifter 14.) Stockholm: Norstedts.

Josephson, O. (2009). Klarspråksforskningens framtid. I C. Nyström Höög (Red.), Medborgare och myndigheter (s. 100-107). Uppsala: Uppsala universitet.

Klart myndighetsspråk - ett handlingsprogram (2014). Undervisnings- och kulturministeriets arbetsgruppspromemorior och utredningar 2014:3. Helsingfors: Undervisnings- och kulturministeriet.

Kjærgaard, A. (2010). Sådan skriver vi - eller gør vi? En undersøgelse af de tekstlige effekter af to sprogpolitiske projekter i Danmarks Domstole og Københavns Kommune og af årsagerne til projekternes gennemslagskraft (Doktorsavhandling, Københavns universitet). København: Københavns universitet.

Kjærgaard, A. (2012). Fra lidenskab til ligegyldighed. En caseanalyse fra Danmarks Domstole af et sprogpolitisk projekts (manglende) gennemslagskraft. Sakprosa, 4(1), art. 1. https://www.journals.uio.no/index.php/sakprosa/article/view/210

Lind Palicki, L. \& Nord, A. (2013). ”Ni ska skriva enkelt - det står i lagen”. Legitimeringar av klarspråk i en utbildning för myndighetsskribenter. I C. Rosén, P. Simfors \& A.-K. Sundberg (red.), Språk $i$ undervisning. Rapport från ASLA:s vårsymposium Linköping, 11-12 maj, 2012 (s. 37-47). Linköping \& Växjö: ASLA, Svenska föreningen för tillämpad språkvetenskap.

Lindgren, B. (Red.). (2007a). Nämnd, inte glömd. Historik över Nämnden för språkvård och Svenska språknämnden 1944-2007. (Skrifter utgivna av Svenska språknämnden 95.) Stockholm: Norstedts.

Lindgren, B. (2007b). Nämnden - en krönika. I B. Lindgren (Red.), Nämnd, inte glömd. Historik över Nämnden för språkvård och Svenska språknämnden 1944-2007 (s. 7-58). (Skrifter utgivna av Svenska språknämnden 95.) Stockholm: Norstedts.

Nord, A. (2011). Att göra någon annans text tydlig. En studie av språkbearbetningen av en myndighetstext. (TeFa 48.) Uppsala: Uppsala universitet.

Nord, A. (2013). "De e du som e experten". Roller, normer och perspektiv i ett textsamtal mellan en språkvårdare och en skribent i myndighetsmiljö. I B. Bihl, P. Andersson \& L. Lötmarker (Red.), 
Svenskans beskrivning 32. Förhandlingar vid trettioandra sammankomsten för svenskans beskrivning, Karlstad den 18-19 oktober 2011 (s. 222-233). Karlstad: Karlstads universitet.

Nord, A. (2014). Högtidstal men ingen debatt? Det svenska klarspråksarbetet som samtida språkpolitiskt projekt. I J. Lindström, S. Henricson, A. Huhtala, P. Kukkonen, H. Lehti-Eklund \& C. Lindholm (Red.), Svenskans beskrivning 33. Förhandlingar vid Trettiotredje sammankomsten för svenskans beskrivning. Helsingfors den 15-17 maj 2013 (s. 333-342). Helsingfors: Helsingfors universitet.

Nyström Höög, C., Söderlundh, H. \& Sörlin, M. (2012). Myndigheterna har ordet. Om kommunikation i skrift. (Språkrådets skrifter 14.) Stockholm: Norstedts.

Nyström Höög, C. (2009). Textvård mellan två kulturer. I C. Nyström Höög (Red.), Medborgare och myndigheter (s. 7-14). (TeFa nr 47). Uppsala: Uppsala universitet.

Rehnberg, H. S. (2012). Inte klart vad som är lätt. Språktidningen, 8/2012. http://spraktidningen.se/artiklar/2012/08/inte-klart-vad-som-ar-latt

Rösare, Sara (2013). Consulting and training. Teaching plain language through editing. Clarity, 70, 11-13.

Seljeseth, I. (2013). Gratulerer, vi har avslått søknaden din om arbeidsavklaringspenger! - en studie av klarspråkarbeidet i NAV april til juli 2012 (Masteroppgave, Universitetet i Oslo). Oslo: Universitetet i Oslo.

Söderlundh, Hedda (2012). Myndighetens textproduktion - skribenter och texter vid Försäkringskassan. I C. Nyström Höög, H. Söderlundh \& M. Sörlin (Red.), Myndigheterna har ordet. Kommunikation i skrift (s. 39-65). (Språkrådets skrifter 14.) Stockholm: Norstedts. 